\title{
Herida por asta de toro en el área maxilofacial: revisión de la literatura y presentación de un caso
}

\section{Maxillofacial injury by bull goring: literature review and case report}

\author{
J.L. Crespo Escudero', J. Arenaz Búa², R. Luaces Rey², Á. García-Rozado', J. Rey Biel', \\ J.L. López-Cedrún', J.J. Montalvo Morenos
}

Resumen: Introducción. Las heridas por asta de toro son relativamente frecuentes en España y países iberoamericanos, donde los espectáculos con estos animales son habituales. Dichas heridas presentan unas características específicas que las diferencian de cualquier otro tipo de heridas.

Material y método. Se presenta el caso de un paciente varón de 18 años, remitido al Hospital 12 de Octubre por el SAMUR tras sufrir una cornada en la región cérvicofacial durante los encierros de San Sebastián de los Reyes en el verano de 2005. El paciente presenta una herida inciso-contusa y anfractuosa desde la región supraclavicular izquierda hasta la comisura labial ipsilateral, con fractura mandibular conminuta a nivel de ángulo izquierdo y cuerpo derecho, fractura dentoalveolar de piezas 1.3 a 2.3 , y laceración severa de la musculatura lingual y suelo de boca.

Discusión. La mayor parte de los politraumatizados por asta de toro son varones, con una edad media de 30. Las victimas suelen ser participantes espontáneos, aficionados a los eventos taurinos y no toreros profesionales.

Si bien las heridas por asta de toro pueden producirse en cualquier parte del cuerpo, la localización más frecuente en todas las series revisadas es el miembro inferior. La región cérvicofacial es una de las menos afectadas en todas las series. Todos los autores coinciden en la baja incidencia de heridas pese a la gran cantidad de aficionados y curiosos atraídos y por esta modalidad de festejos taurinos. Por todas las características particulares del mecanismo de lesión, el tratamiento debe ser urgente y debe realizarse un traslado lo más rápidamente posible a un hospital. Todos los autores están de acuerdo en que inicialmente el paciente con una lesión por asta de toro debe ser considerado un paciente politraumatizado y tratado como tal.

Conclusión. Las heridas faciales por asta de toro son una entidad propia que no tienen equivalente con las distintas etiologías traumáticas de la región craneofacial y cuyas características deben ser conocidas. Aunque son lesiones graves por el peligro de obstrucción de la vía aérea o de shock hemorrágico, su pronóstico es favorable. El éxito en el manejo y tratamiento de los pacientes con este tipo de heridas se fundamenta en una rápida identificación de las lesiones, con el fin de realizar una terapéutica quirúrgica correcta en el menor tiempo posible desde que se produce el accidente.

Palabras clave: Asta de toro; Herida facial

Recibido: 17.07 .2007

Aceptado: 21.07 .2008

1 Médico Adjunto

2 Médico Residente.

3 Jefe de Servicio.

Servicio de Cirugía Oral y Maxilofacial; Hospital Juan Canalejo. La Coruña. España

4 Médico Residente.

5 Jefe de Servicio.

Servicio de Cirugía Oral y Maxilofacial; Hospital 12 de Octubre. Madrid. España

Correspondencia:

Dr. J.L. Crespo Escudero

Servicio de Cirugía Oral y Maxilofacial

Hospital Juan Canalejo

C/ Xubias de Arriba 84

15006 La Coruña. España
Abstract: Introduction. Injuries produced by bull goring are relatively common in Spain and South American countries, where bullfights are scheduled regularly. These wounds have specific characteristics that differentiate them from any other type of wounds.

Material and methods. In the summer of 2005, an 18-year-old male patient was brought to the Hospital 12 de Octubre by emergency services after being gored in the cervicofacial region during the running of the bulls in San Sebastián de los Reyes. The patient had an anfractuous, penetrating and blunt wound extending from the left supraclavicular region to the left lip commissure, comminuted fracture of the left mandibular angle and right mandibular body, dentoalveolar fractures of pieces 1.3 to 2.3, and severe laceration of the lingual musculature and mouth floor.

Discussion. Most patients who suffer multiple injuries as a result of bull goring are men, with a mean age of 30 years. Victims usually are spontaneous participants, bullfighting fans rather than professional bullfighters. The wounds produced by the horns of the bull may be located anywhere in the body, but the most frequent location in all the series reviewed was the lower limb. The cervicofacial region is one of less frequently affected regions in all the series. All authors agree that these injuries have a low incidence despite the huge number of bullfight fans and curious spectators who are attracted by bullfight events. Emergency treatment is required because of the particular characteristics of the mechanism of injury. The patient should be taken as rapidly as possible to a hospital. Authors generally agree that any patient who has been gored by a bull must be considered initially, for purposes of management, as a patient with multiple injuries.

Conclusion. Facial injuries caused by bull goring have no equivalent with other etiologies of trauma in the craniofacial region and surgeons must be aware of their distinctive characteristics. The wounds are serious due to the danger of airway obstruction and hemorrhagic shock, but the prognosis is favorable. The successful management and treatment of patients with this type of injury is based on rapid identification of the wounds in order to execute the correct surgical intervention as soon as possible after the accident occurs.

Key words: Bull goring; Facial 


\section{Introducción}

Las heridas por asta de toro y demás animales astados, son un tipo de lesión frecuente en España y en países iberoamericanos, donde los festejos taurinos (becerradas, vaquillas, encierros, corridas...) son una práctica habitual. Asimismo, pueden verse estas lesiones en otros profesionales que tratan con estos animales, como veterinarios, ganaderos, matarifes, etc. Dadas las características de estos animales, un herido por asta de toro debe de ser considerado un paciente politraumatizado y ser tratado como tal desde su primera asistencia, además de ser sometido al tratamiento específico en función de la región y órganos afectos. Presentan una serie de características especiales (destrozos musculares, varios trayectos, cuerpos extraños, discordancia entre las lesiones aparentes y las existentes, inoculación masiva de gérmenes...) que las hacen singulares tanto en su exploración como en su tratamiento y las diferencian de otro tipo de heridas penetrantes como las producidas por armas blancas o armas de fuego. ${ }^{4,13}$

Es de particular interés a la hora de comprender la magnitud de estas lesiones, conocer el mecanismo de lesión. En el movimiento de embestida, el toro flexiona el cuello y lo extiende a continuación, introduciendo uno o ambos cuernos en el cuerpo de su oponente, produciéndose el primer trayecto ascendente. Posteriormente, el toro continua el movimiento, y levanta a su víctima varios centímetros del suelo, al mismo tiempo que realiza movimientos circulares con la cabeza, actuando el cuerno como el eje de un molino, girando el agredido en torno a él y realizando un movimiento de rotación o derrote, descendiendo la cabeza y subiendo los pies. En consecuencia se producen otros trayectos de lesión y grandes destrozos tisulares. Tras la primera cogida, el cuerpo de la victima puede realizar cualquier movimiento en el espacio y ser embestido nuevamente en cualquier parte del cuerpo. En el momento del impacto la energía cinética se transforma en energía potencial, por lo cual la profundidad de la herida va a depender de la velocidad a la que se realiza el impacto, así como del peso de la res. También van a ser de gran importancia la posición del torero (puntos de apoyo, que determinan la resistencia contra la que ejerce la fuerza el pitón) así como elementos de cotrarresistencia. ${ }^{12}$ Este hecho, junto con el mecanismo de lesión anteriormente expuesto, explican la posibilidad de varios trayectos y heridas que no se identifican en el examen inicial. $1,3,4,7,13$

Para comprender la potencia lesiva del asta del toro de lidia, basta decir que un toro de cuatro años en movimiento y cuatrocientos kilos de peso desarrolla una fuerza de 470 kilos que transmite a sus cuernos desde su tercio posterior a través de un mecanismo de palanca. ${ }^{1}$ García de La Torre describe un trayecto general para las heridas por asta de toro en forma de triángulo, donde el orificio de entrada del pitón es el vértice, estando la base en profundidad. 16,17

Además de las características ponderales del toro existen muchos otros factores que intervienen en el origen y gravedad de las lesiones aparecen expuestos en la tabla 1.

Es importante señalar que generalmente las lesiones más graves suelen recaer en personas con gran componente de ingesta alcohólica, siendo según Monferrer y colaboradores la causa pre-

\section{Introduction}

The wounds produced when a person is gored by a bull or other horned animal are a frequent type of injury in Spain and South American countries, where different events related with bullfighting and fighting cattle (e.g., fighting young bulls, play fighting with calves, the running of bulls, bullfights, and other) are common. Other professionals who handle bulls also can suffer goring injuries, such as veterinarians, cattle owners, slaughterers, etc. Given the characteristics of these animals, any patient who has been gored by a bull must be considered as a patient with multiple injuries and treated as such from the first time the patient is seen. In addition, the patient must receive specific treatment for the injured region and organs affected. These wound have special characteristics (muscular tearing, several wound paths, introduction of foreign bodies, discrepancy between the apparent and actual wounds, massive inoculation of germs, and others) that make them singular in terms of their proper examination and treatment. These characteristics differentiate them from other types of penetrating injuries, such as knife and gunshot wounds. 4,13

Knowledge of the mechanism of injury of horn injuries is of particular interest for understanding the magnitude of these wounds. When the bull charges, it flexes its neck and then extends it, pressing one or both horns into the body of its opponent. This produces the first upward wound path. The bull continues the movement, raising the victim several centimeters from the ground, while tossing its head with a circular movement. The horn acts as a fixed axis while the circular movement of the bull's head turns the victim on its horn(s), lowering the victim's head and raising the feet. This causes new wound paths to open and produces massive tissue damage. After the initial goring, the person's body may shift position and the bull may charge again, goring the person anywhere in the body. At the time of impact, the kinetic energy is transformed into potential energy. The depth of the wound depends on the speed at which the bull was moving at the time of impact and the animal's weight. The position of the person being charged also is important (the points of support of the subject determine how much resistance is offered against the force of the horn), as well as the presence of any elements of counterresistance. ${ }^{12}$ This subject's resistance to the charge, together with the mechanism of injury described, explains why various wound paths and wounds may be present but not identified in the initial examination. 1,3,4,7,13

In order to understand the force that a fighting bull can bring to bear when goring a person, it suffices to say that a four-year-old bull weighing four hundred kilograms and in movement develops a force of 470 kilograms that is transmitted to its horns, where a lever mechanism also comes into

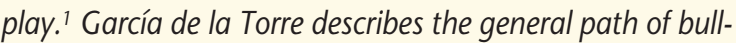
horn wounds as triangular in shape. The entry orifice of the wound is the vertex and the base of the triangle is the deepest part of the wound. ${ }^{16,17}$ 
Tabla 1. Factores que intervienen en el origen y gravedad de lesiones, modificado de Monferrer et al

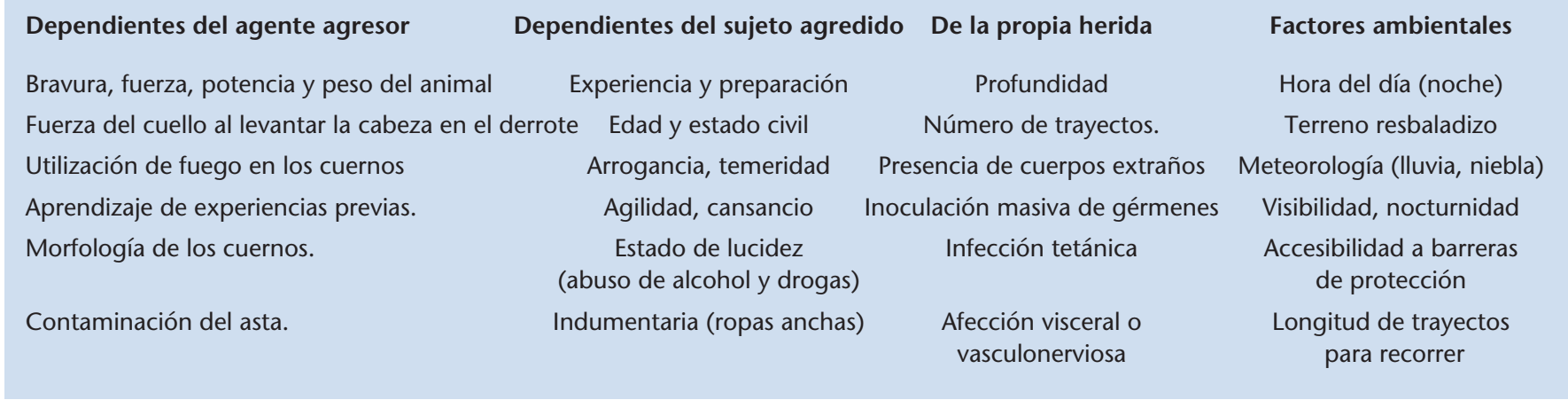

Table 1. Factors contributing to the occurrence and severity of bull goring injuries, modified from Monferrer et al.

Dependant on the aggressive agent

Fierceness, strength, power, and weight of the bull

Strength of the neck in the upward thrust

Points of fire on horns

Taught by previous experience

Morphology of horns

Horn contamination
Dependant on the subject attacked

Experience and preparation

Age and civil status

Arrogance, recklessness

Agility, fatigue

Clearness of mind

(alcohol and drug use)

Clothing (loose-fitting clothes)
Inherent to the wound

Depth

Number of wound paths

Presence of foreign bodies

Massive inoculation of germs

Tetanus infection

Visceral or vasculonervous involvement
Environmental factors

Time of day (Night)

Slippery ground

Weather conditions (rain, fog)

Visibility, night conditions

Accessibility of protective barriers

Length of wound paths disponente más importante para la cogida, asociándose también con una evolución más tórpida y una estancia hospitalaria más prolongada. ${ }^{13}$

Las heridas por asta de toro se pueden clasificar en contusiones y heridas propiamente dichas..$^{1,2}$

1. Las contusiones se dividen en tres tipos:

a. Primer grado: con afectación superficial de la piel y equimosis. Según la intensidad del traumatismo se dividen en "puntazo" (lesión producida por la punta del cuerno, que ocasiona una erosión superficial sin afectar más allá de la piel y tejido celular subcutáneo) y "puntazo corrido" (lesión lineal o que dibuja varios trayectos cutáneos)

b. De segundo grado: con extravasación sanguínea en tejido celular subcutáneo por choque tangencial de la pala del cuerno, denominado "varetazo" o "cornada sobre sano", que produce hematoma o derrame de Morell-Lavalle.

c. De tercer grado: con necrosis de tejidos superficiales o profundos.

2. Las heridas se denominan "cornadas" y son lesiones traumáticas con solución de continuidad en la piel y fascias que daña masa muscular o cavidades orgánicas. La cornada se caracteriza por ser una herida inciso-contusa con orificio de entrada pequeño, pero que puede tener varios trayectos en profundidad que provocan grandes destrozos titulares. $1,2,4,7,8,13$

A estas lesiones tenemos que añadir las fracturas por ser generalmente consecuencia de la embestida del toro, y las quema-
Aside from the bull's weight, many other factors intervene in the origin and severity of the injuries, which are listed in Table 1.

It is important to note that the most serious injuries generally occur in people who also have been drinking. According to Monferrer and colleagues, ${ }^{13}$ alcohol consumption is the most important predisposing factor in goring injuries; it also is associated with a more torpid evolution and more prolonged hospital stay.

The injuries produced by bull goring can be classified into blunt wounds, or contusions, and penetrating, or open, wounds. ${ }^{1,2}$

1. Contusions are divided into three types:

a. Grade 1: Superficial involvement of the skin and ecchymoses. Depending on the intensity of the trauma, these contusions are divided into a "Focused tip impact" (the contusion produced by the tip of the horn, which consists of a superficial erosion that affects only the skin and subcutaneous cellular tissue) and "Sliding tip impact" (a blunt-force injury that is linear or has several wound paths).

b. Grade 2: Contusions with extravasation of blood into the subcutaneous cellular tissue as the result of the tangential impact of the side of the horn, known as a "Varetazo" or "blow with a horn," which produces hematoma or Morell-Lavalle exudation. 
duras cuando la res lidiada lleva algún tipo de fuego prendido en los pitones, como bengalas o antorchas. 7,13

Además de la clasificación anterior en función de la profundidad de las lesiones existe otra clasificación creada por Ramiro A. Pestana-Tirado que divide las lesiones en función de su gravedad en tres grupos: 15

- Grupo 1 o lesiones leves: heridas que requieren solamente "una simple visita a la enfermería" para el examen médico, sin riesgo vital para el paciente ni secuelas de ningún tipo.

- Grupo 2 o lesiones graves: heridas que requieren intervención quirúrgica bajo anestesia local o general de urgencia y/o hospitalización pero sin riesgo vital inmediato para el paciente.

- Grupo 3 o muy graves: lesiones que ponen en juego la vida. del paciente y requieren una intervención quirúrgica bajo anestesia general de extrema urgencia.

\section{Caso clínico}

Presentamos un caso de un varón de 18 años remitido al Hospital 12 de Octubre por el SAMUR, tras sufrir una herida por asta de toro en la región cérvicofacial izquierda durante los encierros de San Sebastián de Los Reyes en Agosto de 2005. Se realiza traslado inminente a quirófano, donde se evidencia la correcta intubación orotraqueal que había sido realizada in situ por el personal sanitario de la plaza de toros. Se comprueba la ausencia de alteraciones respiratorias y cardiovasculares, así como una situación hemodinámica estable.

A continuación, bajo anestesia general, se procede a la realización de traqueotomía reglada y canalización de vía central y periféricas correspondientes. Posteriormente, se procede a una exploración inicial y diagnóstica, donde se evidencia una herida incisocontusa y anfractuosa desde la región supraclavicular izquierda alta hasta la comisura labial ipsilateral. Se objetiva la existencia de una fractura de cuerpo mandibular derecho, fractura conminuta de ángulo mandibular izquierdo, avulsión dental del sector incisal del maxilar superior, así como laceración severa de la musculatura lingual y suelo de boca. Asimismo, se observa una exposición del paquete yugulo-carotídeo izquierdo comprobándose la integridad total del mismo. Se realiza sutura interdental a nivel de los focos de fractura y de las partes blandas adyacentes, con objeto de restaurar provisionalmente la anatomía, y se traslada al paciente al Servicio de Radiología para la realización de TC craneofacial diagnóstico y con el objetivo de descartar la existencia de lesiones del sistema nervioso central y cervicales asociadas. Posteriormente y una vez en quirófano, se realiza laringoscopia directa que excluye la presencia de lesiones laringoesofágicas (Figs. 1 a 3). Se realiza lavado meticuloso con cepillo quirúrgico y solución antiséptica de toda la cavidad oral y tejidos afectos. Se administra vacuna antitetánica y gammaglobulina, y se inicia el tratamiento sistémico intravenoso con amoxilina-clavulánico y metronidazol.

Tras una correcta exposición de los focos de fractura a nivel del cuerpo mandibular derecho y ángulo mandibular izquierdo, favorecido por las características de la propia herida, se realiza reducción y osteosíntesis empleando para ello placas de reconstrucción c. Grade 3: Contusions with superficial or deep tissue necrosis.

2. Open wounds are called "goring wounds" and are traumatic penetrating injuries through the skin and fascias that damage the muscular mass or body cavities. Goring wounds are characterized as being penetrating-blunt wounds with a small entry orifice. There may be several wound paths beneath the tissue surface and major tissue damage. $1,2,4,7,8,13$

To these injuries must be added the fractures that generally result from the charge of the bull. Burns may occur when the bull has flares or torches attached to its horns. 7,13

In addition to the classification based on wound depth, there is another classification created by Ramiro A. PestanaTirado, who divides the injuries into three groups according to their severity. ${ }^{15}$

- Group 1, or mild injuries: wounds that require only "a simple visit to the infirmary" for a medical examination. These wounds do not entail any vital risk to the patient or cause sequelae of any type.

- Group 2, or serious injuries: wounds that require emergency surgery under local or general anesthesia and/or hospitalization, but do not entail any immediate risk to the life of the patient.

- Group 3, or very serious injuries: injuries that threaten the patient's life and require emergency surgery under general anesthesia.

\section{Clinical case}

We report the case of an 18-year-old man who was sent to Hospital 12 de Octubre by the SAMUR emergency services after being gored by a bull in the left cervicofacial region while running the bulls in San Sebastián de los Reyes in August 2005. The patient was transferred immediately to an operating room after correct orotracheal intubation by the health care personnel of the bullring. The absence of respiratory and cardiovascular abnormalities was confirmed, as well as a stable hemodynamic situation.

Next, under general anesthesia, tracheotomy was performed and the necessary central and peripheral veins were cannulated. The initial and diagnostic examinations were made, which disclosed an anfractuous penetrating-blunt wound from the left upper supraclavicular region to the left labial commissure. A fracture of the right mandibular body, comminuted fracture of the left mandibular angle, dental avulsion of the upper maxillary incisor section, and severe laceration of the lingual musculature and mouth floor were found. The left jugulo-carotid package was exposed and checked for its total integrity. An interdental suture was placed at the level of the fracture foci and adjacent soft tissues to provisionally restore the anatomy. The patient was transferred to the Radiology Department for diagnostic craniofacial CT to rule out the existence of associated central ner- 
mandibular 2.4 Synthes ${ }^{\circledR}$, dada la presencia de conminución en una de ellas y el alto potencial de infección del lecho quirúrgico. Se procede a la exodoncia de los restos radiculares remanentes en el sector incisal superior y regularización ósea correspondiente. Se realiza sutura y restauración anatómica de la musculatura cervical, suelo de boca y lengua. Se realiza anastomosis microquirúrgica del nervio mentoniano derecho y lingual izquierdo. Se realiza sutura de piel y mucosa oral. Posteriormente el paciente es traladado al Servicio de UVI-Politrauma donde permanece 36 horas no presentando en este tiempo complicaciones neurológicas ni sistémicas. Tras la derivación a planta, se prosigue con el tratamiento antibiótico durante 10 días, realizándose curas diarias con solución antiséptica de la herida, tanto intraoral como cutánea. No se evidenció patología infecciosa en dicho territorio, presentando una evolución posterior favorable, siendo dado de alta al undécimo día.

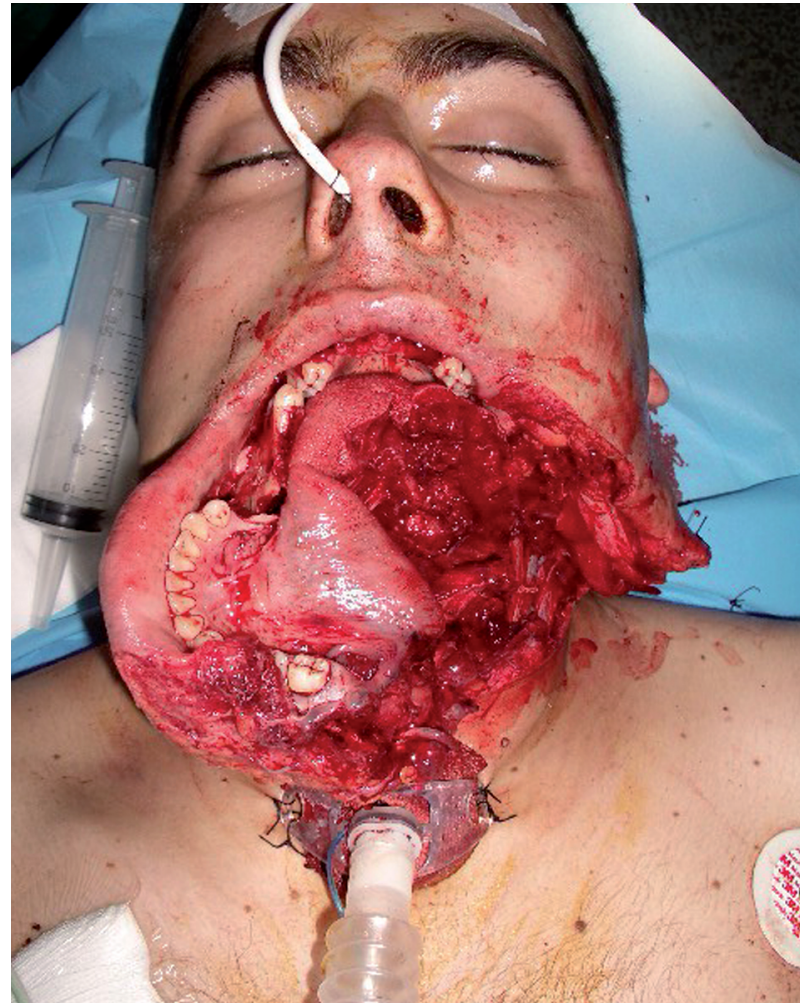

Figura 1. Aspecto del paciente en el momento del ingreso. Figure 1. Appearance of patient at time of admission. vous system and cervical injuries. Later, when the patient was in the operating theater, direct laryngoscopy was performed, which demonstrated the absence of laryngoesophageal injuries (Figs. 1, 2 and 3). The entire oral cavity and dependent tissues were carefully washed with a surgical brush and antiseptic solution. Tetanus vaccine and gammaglobulin were administered and systemic intravenous treatment was begun with amoxicillin-clavulanic acid and metronidazole.

After correct exposure of the fracture foci at the level of the right mandibular body and left mandibular angle, favored by the wound characteristics, the fracture was reduced and osteosynthesis was performed. Synthes ${ }^{\circledR} 2.4$ mandibular reconstruction plates were used due to the presence of comminution in one mandible and the high potential for surgical bed infection. The roots remaining in the upper incisor section were extracted and the bone was treated. Sutures were placed and the cervical musculature, mouth floor, and tongue were restored anatomically. The right mental nerve and left lingual nerve were anastomosed microsurgically. The skin and oral mucosa were sutured. The patient remained in the Intensive Care-Multiple Trauma Unit for 36 hours. He presented no neurologic or systemic complications during his stay. After the patient was transferred to the ward, he continued antibiotic treatment for 10 days. His intraoral and skin wounds were cleaned daily with an antiseptic solution. No infection occurred in this territory and the patient's evolution was favorable. He was released on the eleventh day.

\section{Discussion}

The largest series of bull-goring injuries published to date have been those of Chambres et al. ${ }^{12}$ (1450 patients), Martínez-Ramos et al. ${ }^{13}$ (387 patients), Monferrer et al. ${ }^{10}$ (204 patients), Hernández et al.4 (96 patients), and Rudloff et al. ${ }^{9}$ (68 patients). All these authors agree that most of the multiple injuries caused by goring occur in men with a mean age of 30 years. The age range with the highest frequency of bull horn injuries is between 20 and 30 years. There is a clear predominance of incidence in the months of July, August and September, when bullfighting events are held in most of the towns and cities of Spain. Victims usually are spon- 
Chambres y cols. señalan además una clara y lógica relación directa entre experiencia e incidencia de accidentes (a mayor experiencia menor número de accidentes) pero señalan también que son los matadores los que presentan la más alta tasa de lesiones del macizo cérvicofacial y además presentan las lesiones de mayor gravedad. ${ }^{12}$

Todos los autores coinciden en la baja incidencia de heridas pese a la gran cantidad de aficionados y curiosos atraídos y por esta modalidad de festejos taurinos. ${ }^{13}$

Con respecto a las heridas del área cervicofacial, Chambre y cols. encuentran en su serie que las heridas del macizo facial representan el $8 \%$ de todas las lesiones por asta de toro, 12 dividiéndose al $50 \%$ entre región cervical y región cervical propiamente dicha.

En función de la gravedad, Chambre y cols. afirman que las lesiones más frecuentes son las del grupo 2 de la clasificación de Pestana-Tirado (60\% en su serie), seguidas por las del grupo 3 o muy graves (28\%) y las menos frecuentes son las del grupo 1 o leves (12\%). Sin embargo en lo que a las lesiones faciales se refiere sólo el $10 \%$ son lesiones leves, siendo el resto de grado 2 o 3. Según este autor, son las heridas anfractuosas que afectan a planos superficiales (cutáneo, subcutáneo o muscular) el tipo de lesión más frecuente a nivel del macizo facial (37 de 116), y las fracturas más frecuentemente producidas en este tipo de accidentes son por este orden la de mandíbula, la de malar y la de los huesos propios nasales (18 casos de 116). Los otros tipos de lesiones más frecuentes a nivel del macizo facial son la lesión vascular (arteria facial y lingual), lesiones intraorales que interesan a planos profundos y las lesiones que afectan a cartílagos nasales o auriculares. También observaron en su serie avulsiones dentarias, lesiones del nervio facial y sección del conducto de Stenon ${ }^{12}$ (Tabla 2).

En la serie de Chambre, el 13\% de las lesiones cervicofaciales afectan exclusivamente al cuello, siendo todas ellas de extrema gravedad: sección de la yugular interna (4 casos), sección de la carótida interna (2 casos), lesiones larin-
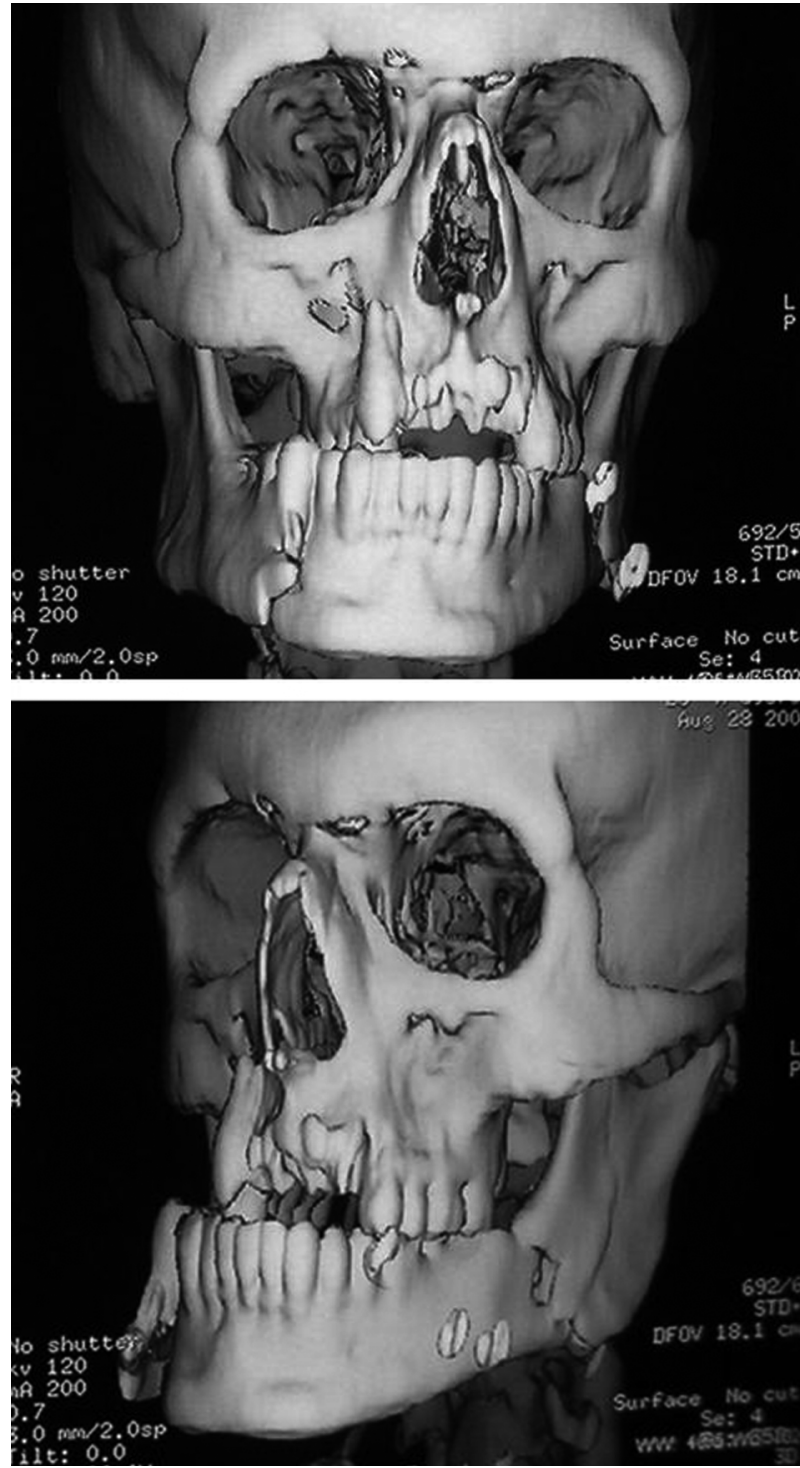

Figura 2. TC con reconstrucción 3D prequirúrgico.

Figure 2. Preoperative CT with three-dimensional reconstruction.

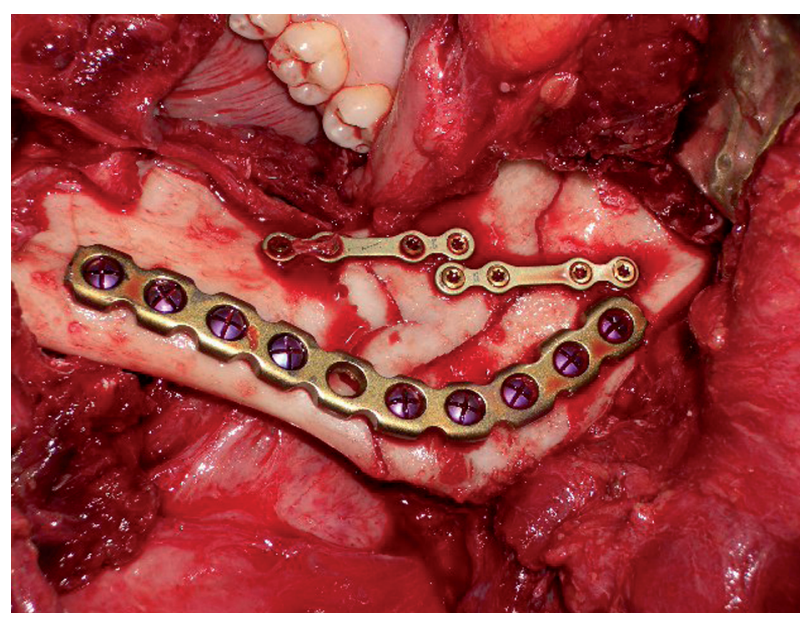

Figura 3. Fractura de ángulo izquierdo.

Figure 3. Fracture of left mandibular angle. taneous participants, people who attend bullfights and other events related with fighting bulls rather than professional bullfighters. ${ }^{13}$

According to all the series reviewed, the most frequent wound is the goring wound ( $81 \%$ in the study of Monferrer et al.13). Although bull horn wounds can occur anywhere on the body, the most frequent location in all the series reviewed is the lower limb, especially the thigh. 1,2,4,10,12,13 Other anatomic regions affected are the abdomen, perineumpelvis, chest, and upper limbs. 1-4,10,13 The cervicofacial region is one of the least affected in all the series, except in the study by Chambres and colleagues, in which it was the third most frequent location in 1450 patients (16\% versus $64 \%$ in the lower limb). ${ }^{13}$

Chambres et al. ${ }^{12}$ pointed out a clear and logical direct relation between experience and the incidence of accidents (more experienced people had fewer accidents), but also reported that the highest rates of cervicofacial injuries and of the most serious injuries was in bullfighters. All the authors coincided in pointing out the low incidence of injuries despite the large number of fans of bullfighting and other festivals with fighting bulls. ${ }^{13}$

Chambres et al. ${ }^{12}$ reported that wounds of the facial area represent $8 \%$ of all wounds caused by bull goring and are divided equally between the facial and cervical regions.

In relation to severity, Chambre et al. affirm that the most frequent injuries are group 2 injuries of the Pestana-Tira- 
gotraqueales, sección del ECM (5 casos), lesión de la glándula tiroides (1 caso) y lesiones esofágicas (2 casos).

También se ha descrito la perforación traqueal o laríngea. 12,24 La herida por asta de toro suele provocar la apertura de la vía aérea por sección de las membranas intercartilaginosas, pues los cartílagos resbalan al contacto con el asta y raramente se fracturan. De ahí que existan dos zonas especialmente afectadas: la intertirohioidea, la más frecuente, con sección de epiglotis, venas yugulares anteriores y nervios laríngeos superiores, y la intercricotiroidea con lesión de los nervios recurrentes y de los lóbulos tiroideos. ${ }^{24}$ Hay que sospechar la existencia de este tipo de lesión ante la salida de aire por los orificios cutáneos de la herida cervical o enfisema subcutáneo, que es un signo constante y puede aparecer horas o días después del accidente. ${ }^{24}$ También pueden existir disnea, disfonía, hemoptisis dependiendo de la magnitud de la lesión. 12,24

Por todas las características mencionadas anteriormente en cuanto a los mecanismos de lesión, el tratamiento debe ser urgente y debe realizarse un traslado lo más rápidamente posible a un hospital, siendo el enfermo valorado de inmediato en el área de Urgencias. ${ }^{13}$ Todos los autores están de acuerdo en que inicialmente el paciente con una lesión por asta de toro debe ser considerado un paciente politraumatizado.

Las heridas del macizo facial, una vez que se mantiene la vía aérea permeable y no hay compromiso ventilatorio ni cardiovascular, son raramente urgencias inmediatas y pueden ser trasladadas a un hospital. Sin embargo, las heridas en el cuello, sí pueden requerir una atención urgente, en la propia enfermería de la plaza de toros, previo al traslado al hospital correspondiente. ${ }^{12}$

De acuerdo con todos los autores, el manejo general de estos pacientes debe incluir:

1. En la región cervicofacial, la mayoría de los autores preconizan de entrada la exploración quirúrgica urgente de la herida bajo Chambres y cols. (2003) y cols. (2003)

Wounds in superficial planes

Tabla 2. Frecuencia de lesiones cervicofaciales en el estudio de

$\begin{array}{lc}\text { Tipo de lesión } & \text { Número de casos } \\ \text { Lesiones del macizo facial: } & \\ \text { Planos superficiales } & 37 \\ \text { Secciones arterio-venosas } & 21 \\ \text { Heridas profundas endobucales } & 19 \\ \text { Fracturas } & 18 \\ \text { Heridas cartilaginosas } & 12 \\ \text { Avulsiones dentarias } & 7 \\ \text { Secciones del VII } & 1 \\ \text { Secciones del Stenon } & 1 \\ \text { Total } & 116 \\ & \\ \text { Lesiones cervicales: } & \\ \text { Heridas en planos superficiales } & 12 \\ \text { Secciones del ECM } & 5 \\ \text { Sección de la yugular interna } & 4 \\ \text { Heridas laringo-traqueales } & 3 \\ \text { Sección de la carótida } & 2 \\ \text { Sección esofágica } & 2 \\ \text { Lesión de la glándula tiroides } & 1 \\ \text { Fractura de vértebras cervicales } & 30 \\ \text { Total } & \end{array}$

Table 2. Frequency of cervicofacial injuries in the study of Chambres

\section{Type of injury}

Bull horn injuries of the facial area: Superficial planes

Arteriovenous section

Endobuccal deep wounds

Fractures

Cartilaginous wounds

Dental avulsion

Sections of the VII cranial pair

Section of Stenon duct

Total

Cervical injuries:

Sternocleidomastoid section

Internal jugular section

Laryngotracheal injury

Carotid section

Esophageal section

Thyroid gland injury

Fracture of cervical vertebrae

Total

Number of cases

37
21
19
18
12
7
1
1
116

12

5

4

3

2

2

1

1

30 do classification $(60 \%$ in their series), followed by group 3, or very serious, injuries (28\%). The group 1, or mild, injuries were the least frequent (12\%). However, only $10 \%$ of facial injuries are mild, the rest are grade 2 or 3 . According to Chambre et al., anfractuous wounds that affect the superficial planes (cutaneous, subcutaneous, or muscular) are the most frequent type of injury in the facial region (37 of 116 cases). The fractures most frequently produced in this type of accident are, in decreasing order, of the mandible, malar, and nasal bones (18 of 116 cases). Other frequent types of injuries of the facial region are vascular injuries (facial and lingual artery), intraoral injuries that affect deep planes, and injuries of the nasal or auricular cartilages. Dental avulsions, facial nerve injuries, and section of the Stenon duct also were observed in their series 12 (Table 2).

In the series of Chambre, $13 \%$ of the cervicofacial injuries affected only the neck. All of them were extremely serious: section of the internal jugular (4 cases), section of the internal carotid (2 cases), laryngotracheal injuries, sternocleidomastoid section (5 cases), thyroid gland injury (1 case), and esophageal injuries (2 cases).

Tracheal or laryngeal perforation has been described. ${ }^{12,24}$ Bull goring wounds usually produce airway opening due to section of the intercartilaginous membranes; the cartilages slip under contact with the horn and rarely fracture. Two zones are especially affected: most frequently, the interthyrohyoid zone with section of the epiglottis, anterior jugular veins and superior laryngeal nerves, followed by the intercricothyroid zone with injury of the recurrent nerves and thyroid lobes. ${ }^{24}$ The existence of this type of injury should be suspected if air leaks from the cutaneous orifices of the cervical wound or subcutaneous emphysema occurs. This is a constant sign that can appear hours or days after the accident.24 Dysp- 
anestesia general,13,24 y exploración minuciosa de los posibles trayectos de lesión y limpieza de los mismos. ${ }^{12}$ En el lugar del accidente la intubación es la única posibilidad que permite el transporte a un medio hospitalario en el caso de una herida cervicofacial. ${ }^{24}$ De todos modos, en general es preferible la traqueotomía a la intubación, pues en las lesiones del macizo facial, la intubación puede ser extremadamente complicada (gran edema de glotis que altera las estructuras anatómicas con desplazamiento posterior de la epiglotis, traumatismos laríngeos o traqueales, acúmulo de sangre en la vía aérea con riesgo de introducción de aire o dientes en la vía aérea, etc.) y las lesiones medulares cervicales pueden ser agravadas en el intento de intubación, 18,24 aunque raramente se podrá realizar en lugar del accidente y será realizada al llegar al hospital. ${ }^{24}$ En el centro hospitalario la maniobra de elección es la traqueotomía.

2. Antibioterapia pre y postquirúrgica y vacunación antitetánica: las heridas por asta de toro son muy sucias, debiendo considerarse contaminadas desde el momento en que se producen, con probabilidad de complicaciones infecciosas graves. ${ }^{10}$ La vacunación antitetánica y la administración de la gammglobulina debe ser imperativa y sistemática en todos los pacientes con este tipo de heridas.1,2,12,14 De igual manera los cuernos son portadores de bacterias tanto aerobias como anaerobias, por lo que es prioritaria la profilaxis y el tratamiento antibiótico en estos pacientes. ${ }^{1,2,4,8}$ Martínez-Ramos y cols. ${ }^{10}$ señalan que la combinación antibiótica más utilizada fue metronidazol y amoxicilina-clavulánico con buenos resultados. Otras combinaciones utilizadas con buenos resultados fueron el metronidazol y la tobramicina (o amikacina) o el metronidazol junto con tobramicina (o amikacina) y ampicilina. Chambre también acepta como adecuada la combinación de ceftriaxona y metronidazol. ${ }^{12}$ Sea cual sea la combinación antibiótica utilizada la cualidad exigible ha de ser la de cubrir tanto gérmenes aerobios gramnegativos y grampositivos, y anaerobios.

3. Lavado exhaustivo con suero fisiológico y solución antiséptica (agua oxigenada

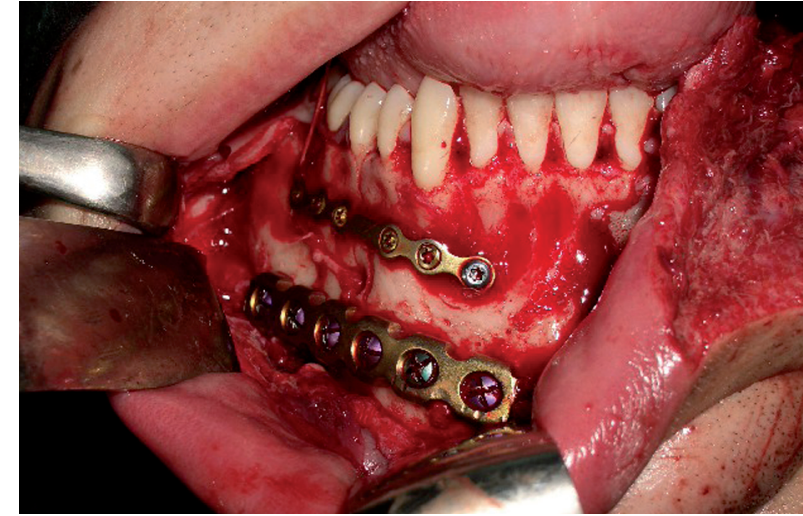

Figura 4. Fractura de cuerpo mandibular derecho.

Figure 4. Fracture of right mandibular body.

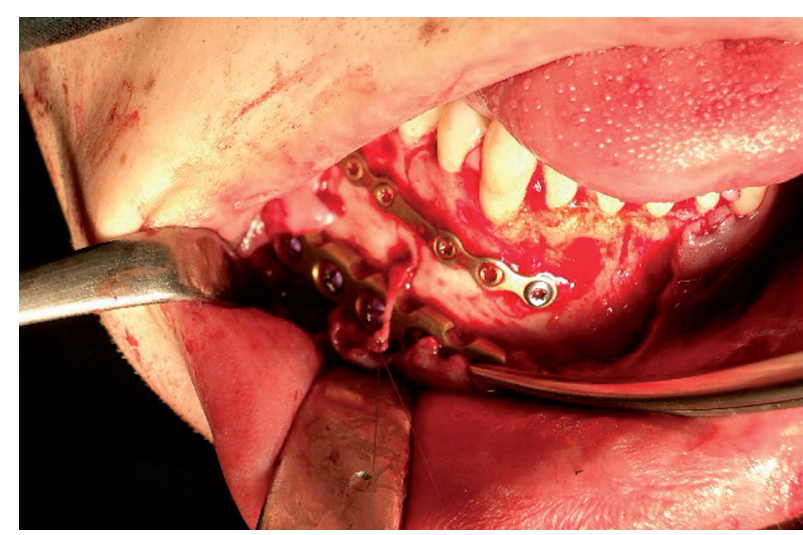

Figura 5. Setalle de la sutura del nervio mentoniano.

Figure 5. Detail of the mental nerve suture.

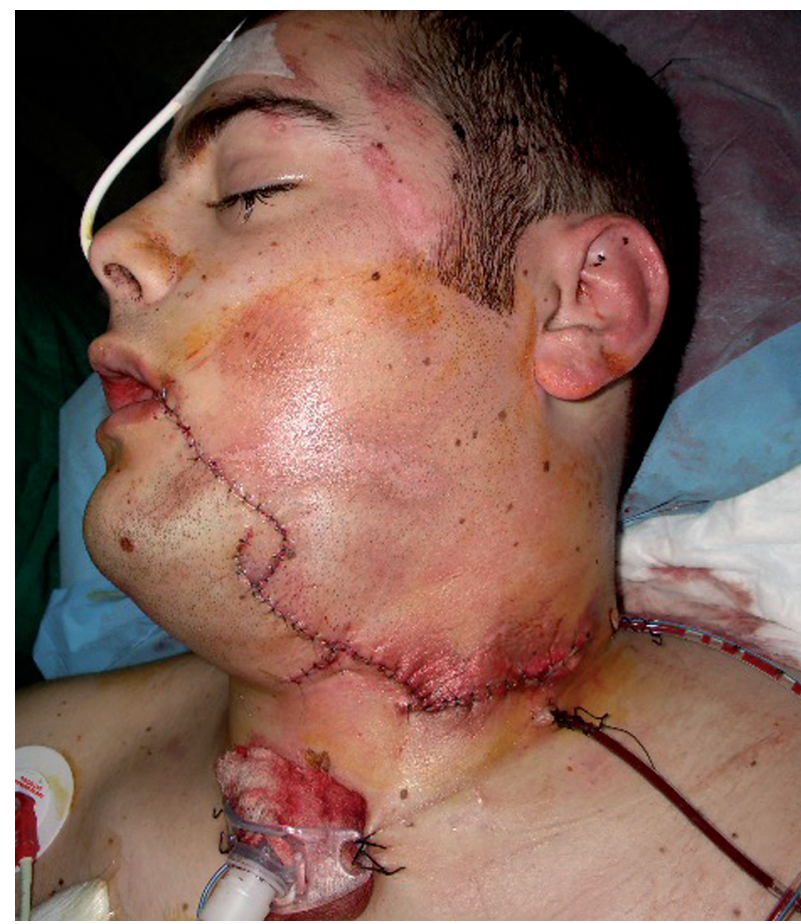

Figura 6. Aspecto en el postoperatorio inmediato.

Figure 6. Appearance in immediate postoperative period. nea, dysphonia, and hemoptysis also may be present, depending on the magnitude of the injury. ${ }^{12,24}$

In view of the characteristics discussed above with the mechanisms of injury, treatment must be urgent and the patient should be transferred to a hospital as rapidly as possible. The patient must be assessed immediately in emergency services. ${ }^{13}$ All authors agree that a patient who has been gored by a bull must be considered initially as a patient with multiple trauma.

Wounds in the facial area rarely require emergency measures other than ensuring airway patency and checking respiratory and cardiovascular function, after which the patient can be transferred to a hospital. However, neck wounds may require immediate attention in the infirmary of the bullring before the patient is transferred to the hospital. ${ }^{12}$

All authors agree that the general management of these patients must include:

1. In the cervicofacial region, most authors recommend emergency surgical examination of the wound under general anesthesia ${ }^{13,24}$ and meticulous examination of all possible wound paths of the injury, together with cleaning of the wound paths. ${ }^{12}$ At the accident site, intubation 
y/o povidona yodada) y limpieza de todo cuerpo extraño (astillas del cuerno, piedras, tierra, restos de ropa, vidrios...).

4. Desbridamiento amplio de los tejidos desvitalizados, aunque intentando ser lo más económicos posible en los planos cutáneos ${ }^{12}$ y Friedrich refrescando sus bordes.

5. Se llevará a cabo una hemostasia cuidadosa y la reconstrucción plano por plano de la zona. En caso de que exista pérdida de sustancia, la reconstrucción no será realizada de urgencia sino de forma diferida, según la mayoría de los autores. ${ }^{12}$

Con respecto a las complicaciones, en general las heridas por asta de toro están gravadas por una alta tasa de infecciones (desde un $9,4 \%$ en el estudio de 96 pacientes realizado por Hernández y cols. hasta un $54,4 \%$ en el realizado por Idikula y cols., donde fueron estudiados 54 pacientes), siendo la complicación más frecuente en todas las series estudiadas. ${ }^{1,4}$

La estancia hospitalaria en nuestro caso fue de 7 días. Otras series presentan una estancia media de 5,4 días 1 a 10 días. $4,10 \mathrm{~A}$ pesar de la gravedad de alguna de estas lesiones, se considera que el índice de mortalidad es bajo en todas las series consultadas con un máximo de 4,1\%,6 siendo las causas más frecuentes el shock hipovolémico, el shock séptico y la gangrena gaseosa.6,10 La mortalidad en las heridas abiertas en el cuello es del al $6 \%$, siendo la causa más frecuente la herida vascular (40\%), seguida de la obstrucción de la vía aérea y de las lesiones esofágicas. ${ }^{24}$

\section{Conclusiones}

Las heridas faciales por asta de toro son una entidad propia que no tienen equivalente con las provocadas por otras etiologías traumáticas y cuyas características es necesario conocer. Aunque son lesiones graves por el peligro de obstrucción de la vía aérea o de shock hemorrágico, su pronóstico es favorable. El éxito en el manejo y tratamiento de los pacientes con este tipo de heridas se fundamenta en una rápida identificación de las lesiones, con el fin de realizar una terapéutica quirúrgica correcta en el menor tiempo posible desde que se produce el accidente.

\section{Bibliografía}

1. Mansilla Roselló A, Fuentes Martos R, Astruc Hoffmann A, Flores Arcas A, Albert Vila A, Fernández Valdearenas R, Granda Páez R, Ruiz De Adana Garrido A, López Yébenes A. Estudio de 44 heridas por asta de toro. Cirugía Española 1998;63:36-9.

2. Olsina J. Traumatismos por asta de toro. Med Clin 1975;65:541-542.

3. Fernández M. Cirugía en las heridas por asta de toro. An Real C Nac Med 1984; 101:375-96.

4. Hernández E, Gómez-Perlado B, Villaverde M, Vaquero G, Marugán JA, Besharat F y cols. Heridas por asta de toro. Estudio de 96 pacientes. Cir Esp 1996;59: 156-9.

5. Mateo AM, Larrañaga JR, Vaquero C, Rodríguez-Camarero S, González Fajardo JA, De Marino G. Traumatismos vasculares por asta de toro. Anal Acad Med Cir Vall 1990;28:319-29.

6. Shukla HS, Mittal DK, Naithani YP. Bull Horn Injury: A clinical study. 1977;9:1647. is the only option for transporting a patient with a cervicofacial wound to a hospital. ${ }^{24}$ In any case, tracheotomy generally is preferable to intubation because intubation can be extremely complicated in injuries of the facial area (glottis edema deforms anatomic structures with posterior displacement of the epiglottis, laryngeal or tracheal trauma, accumulation of blood in the airway, risk of introducing air or teeth in the airway, etc). Cervical spinal cord injuries may be aggravated by attempted intubation, 18,24 so it will rarely be done at the site of the accident and will be performed when the patient reaches the hospital. ${ }^{24}$ Once there, the procedure of choice is tracheotomy.

2. Preoperative and postoperative antibiotic therapy and tetanus vaccination: bull horn injuries are very dirty and should be considered contaminated and likely to develop serious infective complications from the time of occurrence. ${ }^{10}$ The tetanus vaccination and gammaglobulin administration are imperative and should be given systematically to all patients with this type of wound. 1,2,12,14 Horns carry aerobic and anaerobic bacteria, so antibiotic prophylaxis and treatment are a high priority in these patients. 1,2,4,8 Martínez-Ramos et al. ${ }^{10}$ indicate that the antibiotic combination most often used is metronidazole and amoxicillin-clavulanic acid, with good results. Other combinations used with good results are metronidazole and tobramycin (or amikacin) or metronidazole with tobramycin (or amikacin) and ampicillin. Chambre also accepts ceftriaxone and metronidazole as a suitable combination. ${ }^{12}$ Whatever antibiotic combination is used, it is indispensable that it cover aerobic, gram-negative and gram-positive, and anaerobic microorganisms.

3. Wounds must be cleaned exhaustively with saline solution and an antiseptic solution (hydrogen peroxide and/or povidone-iodine) and all foreign bodies (horn splinters, stones, dirt, remains of clothing, glass, and other) must be removed.

4. Devitalized tissues must be debrided thoroughly, although we should be as economic as possible on skin planes 12 and follow Friedrich in refreshing the margins.

5. Bleeding should be controlled carefully and the area should be reconstructed by planes. If loss of substance occurs, reconstruction should be deferred according to most authors. ${ }^{12}$

Generally speaking, the complications of bull goring injuries include a high rate of infections (from $9.4 \%$ in the study of 96 patients by Hernández et al. to $54.4 \%$ in the study of 54 patients by Idikula et al.). Infection is the most frequent complication in all the series studied.1,4

Our patient's hospital stay was 7 days. Other series report a mean stay of 5.4 days 1 to 10 days. ${ }^{4,10}$ Despite the severity of some of these injuries, the mortality rate is considered low in all the series consulted, with a maximum of $4.1 \%{ }^{6}$ The most frequent causes of death are hypovolemic shock, septic shock, and gaseous gangrene.6,10 The mortality in open 
7. Fernández Zúmel M. Cirugía en heridas por asta de toro. An Real Ac Nac Med 1984;28:319-29.

8. Alaústre Vidal A, Rull Lluch M, Caps Ausas I. Infecciones de los tejidos blandos. En: Salvat Lacombe JA, Guardia Massó J (eds). Urgencias Médico Quirúrgicas. Barcelona: Uriach, 1987;289-322.

9. Rudloff U, Gonzalez V, Fernández V, Holguin E, Rubio G, Lomelin J, Dittman M, Barrera. Chirurgica Taurina: a 10-year experience of bullfight injuries. / Trauma 2006;61:970-4.

10. Martinez-Ramos D, Miralles-Tena JM, Escrig-Sos ], Traver-Martinez G, CisnerosReig I, Salvador-Sanchis JL. Bull horn wounds in Castellon General Hospital. A study of 387 patients. Cir Esp 2006;80:16-22.

11. Sheldom Lloyd M. Matador versus Taurus: bull gone injury. Ann R Coll Surg Engl 2004;86:3-5.

12. Chambres O, Giraud C, Gouffrant JM, Debry C.A detailed examination of injuries to the head and neck caused by bullfighting, and other surgical treatment: the role of the cervico-facial surgeon. Rev Laryngol Otol Rhinol 2003;124:221-8.

13. Monferrer Guardiola R. Heridas por asta de toro. Aspectos clínico-epidemiológicos de 204 casos asistidos en el Hospital General de Castelló, durante el período 1978-1988. Ciencia Médica 1990;7:262-71.

14. Navarro Roldán J, Castell Campesino L, Escrig Sos J y cols. Heridas por asta de toro, experiencia sobre 31 casos. Ciencia Médica 1990;7:118-24.

15. Pestana-Tirado RA, Ariza Solano GJ, Barrios Air, Oviedo Castaño L. Trauma por cornada de toro. Experiencia en el Hospital Universitario de Cartagena. Trib Med 1997;96:67-83.

16. Rao P, Batí F, Gaudino J y cols. Penetrating injuries of the neck: criteria for exploration. J Trauma 1983;1:47-9.

17. Belinkie S, Russell J, da Silva J, Becker D. Management of penetrating neck injuries. J Trauma 1983;3:235-7.

18. Faucon B, Defrennes D. Urgence devant une plaie cervicale. Encycl Med Chir Urgentes 1994;24:2-20.

19. Navsaria P, Omoshoro-Jones J, Nichol A. An análisis of 32 surgically manager penetrating carotyd artery injuries. Eur J Vasc Endovasc Surg 2002;24:349.

20. Moeng S, Boffard K. Penetrating neck injuries. Scand Surg 2002;91:33-40.

21. Faucon B, Deffrennes D. Urgence devant une plaie cervicale. Encycl Med Chir Urgences 1994;24-002-A-20.

22. Giraud C, Gouffrant J. Traumatismes arteriels par cornes de taureau. AERCV. Ed. Actualités de Chirurgie Vasculaire 1995;453-67.

23. Chambres O, Thaveau F, Gabbaï M, Giraud C, Gouffrant JM, Kretz JG. Une discipline atypique: la chirurgie taurine. À propox de deux observations. Ann Chirur 2005; 130:340-5.

24. Lahoz Zamarro MT, Valero Ruiz J, Royo López J, Cámara Jiménez F. Traumatismo abierto por asta de toro. Anales ORL Iber-Amer 1990;17:77-84. neck wounds is $6 \%$, the most frequent cause of death being a vascular wound (40\%), followed by airway obstruction and esophageal injuries. ${ }^{24}$

\section{Conclusions}

The facial injuries resulting from bull goring are a distinct entity and are not equivalent to injuries caused by other types of trauma. Surgeons must be aware of the characteristics of these injuries. Although they are serious injuries, due to the danger of airway obstruction or hemorrhagic shock, their prognosis is favorable. The successful management and treatment of patients with this type of injury is based on rapid examination of the wounds in order to perform the correct surgical intervention as soon as possible after the accident occurs. 